quotas have to be fixed on the basis of inadequate data, but this is a reason for being cautious and conservative, not for consistently fixing them too high, as has been done, so that stock after stock has to be withdrawn from exploitation. The proof of the pudding is in the eating, and the headlong fall of the stocks of the great whales is proof that this pudding has been overcooked.

The only achievement of the Tokyo special meeting was to curb slightly the excessive demands of the United States on behalf of its Inuit (Eskimo) citizens to be allowed to overexploit the Bering Sea stock of bowhead whales, probably the world's rarest great whale apart from the almost extinct North Atlantic right whale. The numbers being talked about were trivial, but still excessive when the putatively correct quota, as recommended at Canberra, was nil. In the event a catch of 12 landed or 18 struck whales was agreed to, approximately half of what the US had asked for. One problem is the inefficiency of Inuit whaling, for more whales are struck than landed. Regretfully the US has shown that when the chips are down it is little better than Japan or Russia. By persuading the main Commission to overrule a decision of the Scientific Committee that was agreed to be soundly based, the US jeopardised the whole future of whale conservation. Apparently nobody can accept that, if an endangered stock is to survive, let alone increase, none at all must be harvested. Certainly there were intense domestic political pressures in the US, but what good can it do the Inuit to drive a seriously endangered whale still nearer to extinction? Their cultural heritage will soon be gone for ever.

\title{
Successful Start for the Seaweed Eaters
}

\author{
Peter Jewell
}

The Orkney sheep are a rare breed of unimproved island livestock that have caused much concern to conservationists. Their stronghold is the island of North Ronaldsay, where they have gained renown by subsisting almost exclusively on seaweed. The islanders protect them and they form an integral part of the local economy. But to retain the whole population on one island was not sound conservation policy, and in 1971, the Fauna Preservation Society decided to back the search for an island that would support a second and independent flock. In 1973 an organisation to promote the preservation of rare domestic animal breeds was launched as the Rare Breeds Survival Trust (RBST), which took on the responsibility for the Orkney project (see Oryx, XII: 516, Nov. 1974). FPS sends an observer to the Council. In 1974 the Trust was able to buy the island of Linga Holm, near Stronsay, and also a flock of 178 sheep from North Ronaldsay to put on it. That autumn this foundation flock, comprising 7 rams, 114 ewes and 57 lambs, was released on the island. They have been permitted to reproduce and multiply without hindrance or artificial selection, and the flock has run as a semi-feral, random-breeding unit.

In 1977 a working party, of which I was a member, visited the island to shear, dip and cull the sheep, and took the opportunity to count and assess the status of the flock. A full account of our activities by Lawrence Alderson, the Technical Consultant to the RBST, appeared in the Trust's journal Ark (September 1977, IV: 198-301). 


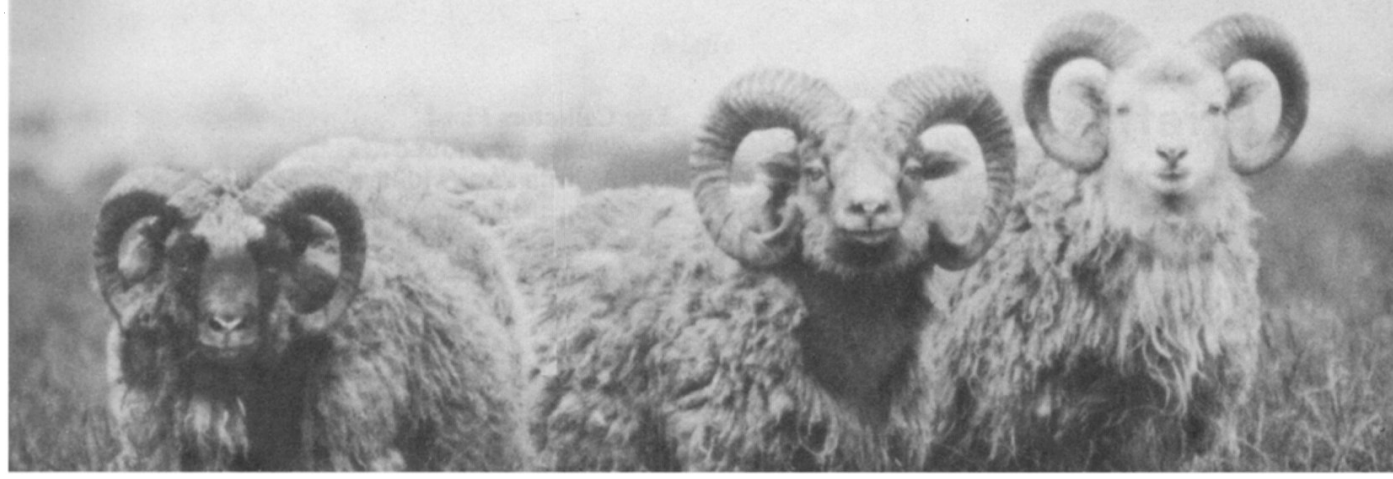

On Linga Holm

We managed to pen almost 90 per cent of the flock - over 700 animals - for shearing, and next day, when the sheared animals had been released, made a census of the whole island. The grand total came to 828 sheep, comprising 203 rams, 371 ewes and 254 lambs. The rams were running in large groups and included one especially impressive bunch of 38 animals.

This stocking rate is much higher than we had intended originally, and we marked about 350 animals to be culled in order to reduce the flock to a conjectured optimum of about 200 ewes plus rams and followers; this should allow adequate kelp for all the sheep so that none are forced back to a diet of grass. It was noticeable that the interior of the island had been grazed more heavily than in previous years. If the numbers are not controlled there is a danger that some strains or families within the flock will revert to subsisting on the herbage, although the existing flock of 800 sheep were obviously in good health. The criteria of slection for the breeding stock were teeth, horns, age, colour and freedom from defects. Preference was given to old ewes that were sound and in good condition. Colour was not a factor of high priority but we tried to main tain the breed's full range of colours - white, grey, grey-brown, black and moorit. Lawrence Alderson writes that as he left the island, "a fresh westerly was throwing up a rich harvest of kelp on the falling tide, and the sheep thronging industriously on the rock shelves at the North Taing and the north-western corner of the island, where the most abundant seaweed lay, were positive proof of the success of the Trust's first major conservation project.'

\section{Otter Havens}

By the end of 1977 the two workers for the Otter Haven Project, Angela King and Angela Potter, had established sixteen havens, with the consent of the landowners, eight in Dorset (Rivers Frome and Piddle) and eight in Devon (Yeo, East Yeo, Tavy and Taw); they are monitoring them monthly in order to assess their effectiveness. Many landowners have shown great interest in the project, and offers of land for havens have come from all over the country. One useful opportunity for research on otter behaviour is on the River Piddle where the Water Authority is doing some major maintenance work and has agreed that the two Angelas (as they are, of course, known) should monitor the effects of this disturbance on the otters. They are also planning to discuss with drainage engineers in each water authority area the best ways to minimise disturbance to otters during such operations. The Otter Haven Project was launched by the Vincent Wildlife Trust, which is funding it, and FPS. 